TITLE:

NOTES ON THREE SPECIES OF

HARPACTICOID COPEPODA, PORCELLIDIUM SP., PELTIDIUM OVALE THOMPSON \& A. SCOTT, AND DACTYLOPUSIA (?) PLATYSOMA THOMPSON \& A. SCOTT, FROM TANABE BAY-

AUTHOR(S):

Gamo, Sigeo

\title{
CITATION:
}

Gamo, SigeO. NOTES ON THREE SPECIES OF HARPACTICOID COPEPODA, PORCELLIDIUM SP., PELTIDIUM OVALE THOMPSON \& A. SCOTT, AND DACTYLOPUSIA (?) - PLATYSOMA THOMPSON \& A. SCOTT, FROM TANABE BAY-, PUBLICATIONS OF THE SETO MARINE BIOLOGICAL LABORATORY 1969, 16(5): 345-361

ISSUE DATE:

1969-01-31

URL:

http://hdl.handle.net/2433/175553

RIGHT: 


\title{
NOTES ON THREE SPECIES OF HARPACTICOID COPEPODA, PORCELLIDIUM SP., PELTIDIUM OVVALE THOMPSON \& A. SCOTT, AND DACTYLOPUSIA (?) PLATYSOMA THOMPSON \& A. SCOTT, FROM TANABE BAY ${ }^{1)}$
}

\author{
Sigeo GAMÔ
}

Faculty of Education, Yokohama National University, Yokohama

With 7 Text-Figures

The present paper deals with three species of Harpacticoid Copepoda, Porcellidium sp. (Porcellidiidae), Peltidium ovale Thompson \& A. Scotт (Peltidiidae) and Dactylopusia (?) platysoma Tномpson \& A. Scotт (Thalestridae ?) from Tanabe Bay, Kii Peninsula. They were found in a small collection of Copepoda collected by the Dragonet II, an opening-closing quantitative trawl, during a survey of the meioepibenthos fauna of Tanabe Bay, in March 1966 (see Bieri and TokiokA, 1968).

I wish to express my gratitude to Professor Tune SakaI for his interest and encouragement. I am greatly indebted to Associate Professor Takasi TokiokA of the Seto Marine Biological Laboratory for his kind help and for the specimens which were offered me at my disposal for study. My warmest thanks are also due to Professor Huzio Utinomi of the Seto Marine Biological Laboratory and Professor Masao Iwasa of the Seikei University for their valuable advices and encouragement.

\section{Porcellidium sp.}

(Figs. 1, 2)

Ovigerous female, total length $0.69 \mathrm{~mm}$, greatest diameter $0.46 \mathrm{~mm}$, carrying 14 eggs on the underside of the abdomen.

The general shape of the body is characteristic for the genus, strongly compressed dorso-ventrally, in outline broadly ovoid as seen from above. The whole dorsal surface of the body integument has a characteristic reticulated appearance as though the integument appears to be covered by minute, hollowed depressions (Fig. 1, B, $\mathrm{C}$ and $\mathrm{J}$ ). There is no trace of a median eye. The specimen preserved in formalin is deeply reddish in colour.

1) Contributions from the Seto Marine Biological Laboratory, No. 502 and Studies of Meiobenthos by Dragonet, No. 6 .

Publ. Seto Mar. Biol, Lab., XVI (5), 345-361, 1969. (Article 26) 
The head and the 1st thoracic somite are fused to form the cephalic somite. The anterior part of the cephalic somite is rounded, almost semicircular, slightly produced between the basal parts of the antennulae and supporting a distinctly visible rostral base, which is distinctly outlined in square (Fig. 1, A.) The rostrum is invisible from above, pointing downward, triangular in shape with a blunt apex (Fig. 1, C). The 2nd and 3rd thoracic somites are of about the same length, epimeral plates are well developed; 3rd with a hairlike spine on each side. The cephalic somite and the epimeral plates of the 2 nd and 3 rd thoracic somites are fringed with a narrow hyaline lamella. The 4 th thoracic somite is visible from above, but the epimeral plates are undeveloped. The 5th thoracic somite is visible in dorsal aspect as a narrow strip, to which the wing-shaped 5th legs are attached. The abdomen is composed of two parts, the big genital complex and the small anal part, each apparently resulting from fusion of some somites (Fig. 1, J).

The furcal rami are lamellar, hairy and twice as long as broad; the internal angle is straight; the external margin is rather convex, with the result that the greatest diameter is at about its posterior one-third; the extreme apex is rounded in the middle portion; five short marginal setae and two appendicular setae are on the surface of each ramus. The position of the marginal setae are shown in Fig. 1, J.

The 5th legs, in a dorsal view of the whole body, appear as a wing-shaped structure their apex almost reaches the end of the furcal rami. There is a distinct longitudinal carina on the legs; the external margin is fringed with spiniform hairs; there are two short setae at the apex, one rather stout seta inserting about halfway along the external margin and one appendicular seta on the surface of the distal portion.

The antennule (Fig. 1, D) is short, 6-segmented. The 2nd segment is fairly long; the 4th segment with a very short conical process bearing an aesthetasc and several setae. The setation of the antennule is as shown in Fig. 1, D.

The antenna (Fig. 1, E) with the basipodite and the 1st endopodal segment separate. The exopodite is apparently 1 -segmented and provided with a total of 6 strong plumose setae and one small spine at the apex. The 2nd endopodal segment has 6 setae, one of which is knife-shaped, 3 are geniculated at the distal portion, and 2 are setose.

The praecoxa of the mandible is elongate; the cutting edge is small and bears six teeth (Fig. 1, F). The palp is strongly compressed and greatly developed. The coxopodite and basipodite are fused together, with four marginal setae. The endopodite and exopodite are well developed, unsegmented; the former bears 8 marginal setae and 1 appendicular seta and the latter bears 5 marginal setae and 1 appendicular seta (Fig. 2, A). Most of the marginal setae are plumose and thickened proximally.

The maxillula is shown in Fig. 1, G.

The maxilla (Fig. 1, H) is small, with a distinct praecoxal endite, bearing 3 setae, and a small coxal endite, carrying a single seta. The basipodite and basal endite 


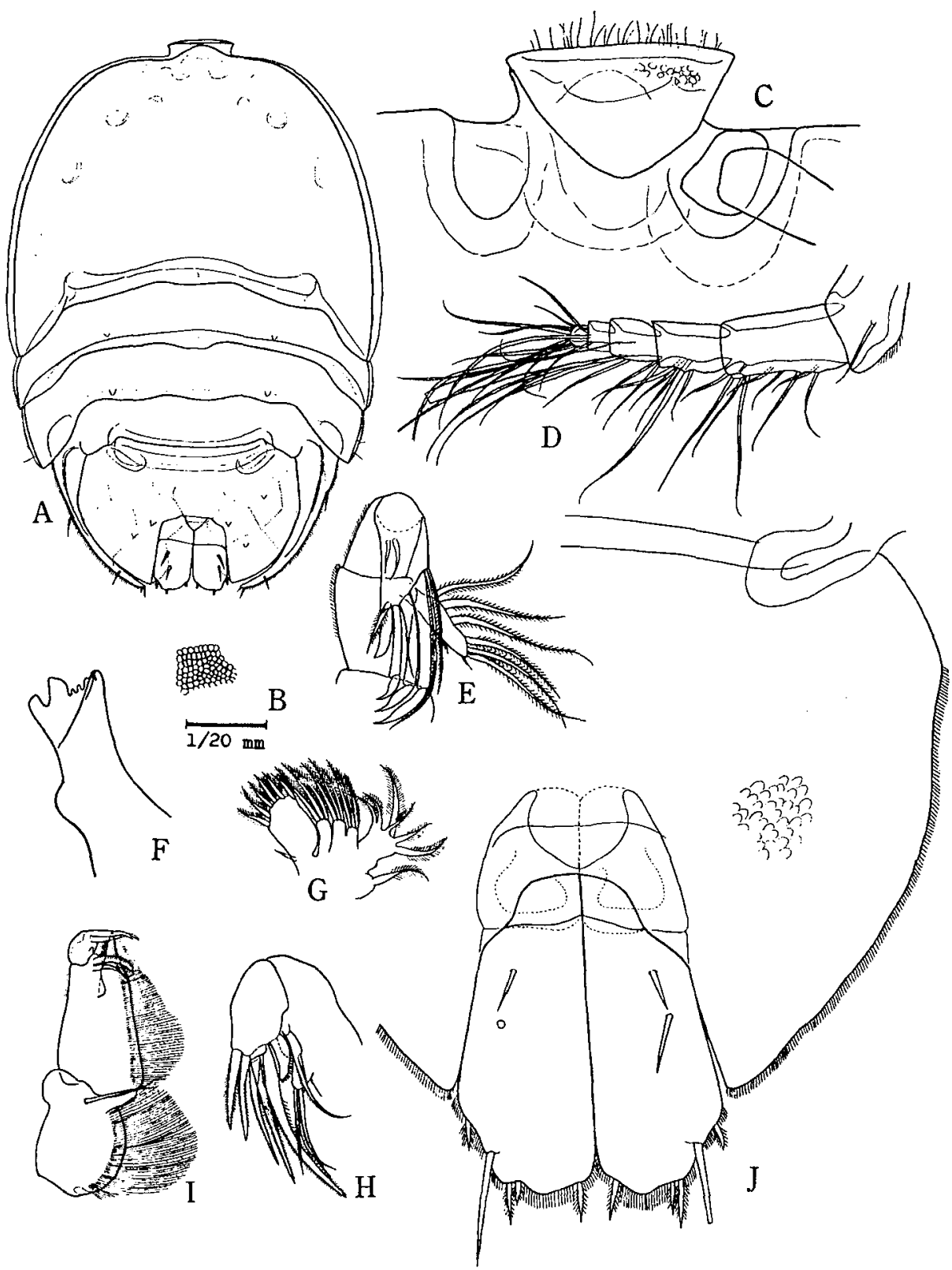

Fig. 1. Porcellidium sp., ovigerous female, $0.69 \mathrm{~mm}$ long.

A: whole animal, dorsal. B: texture of integument surface. $C$ : rostrum and frontal region, ventral. D: antennule. E: antenna. F: mandibular praecoxa. G: maxillula. H: maxilla. I; maxilliped. J : abdomen, right and posterior parts, dorsal. 


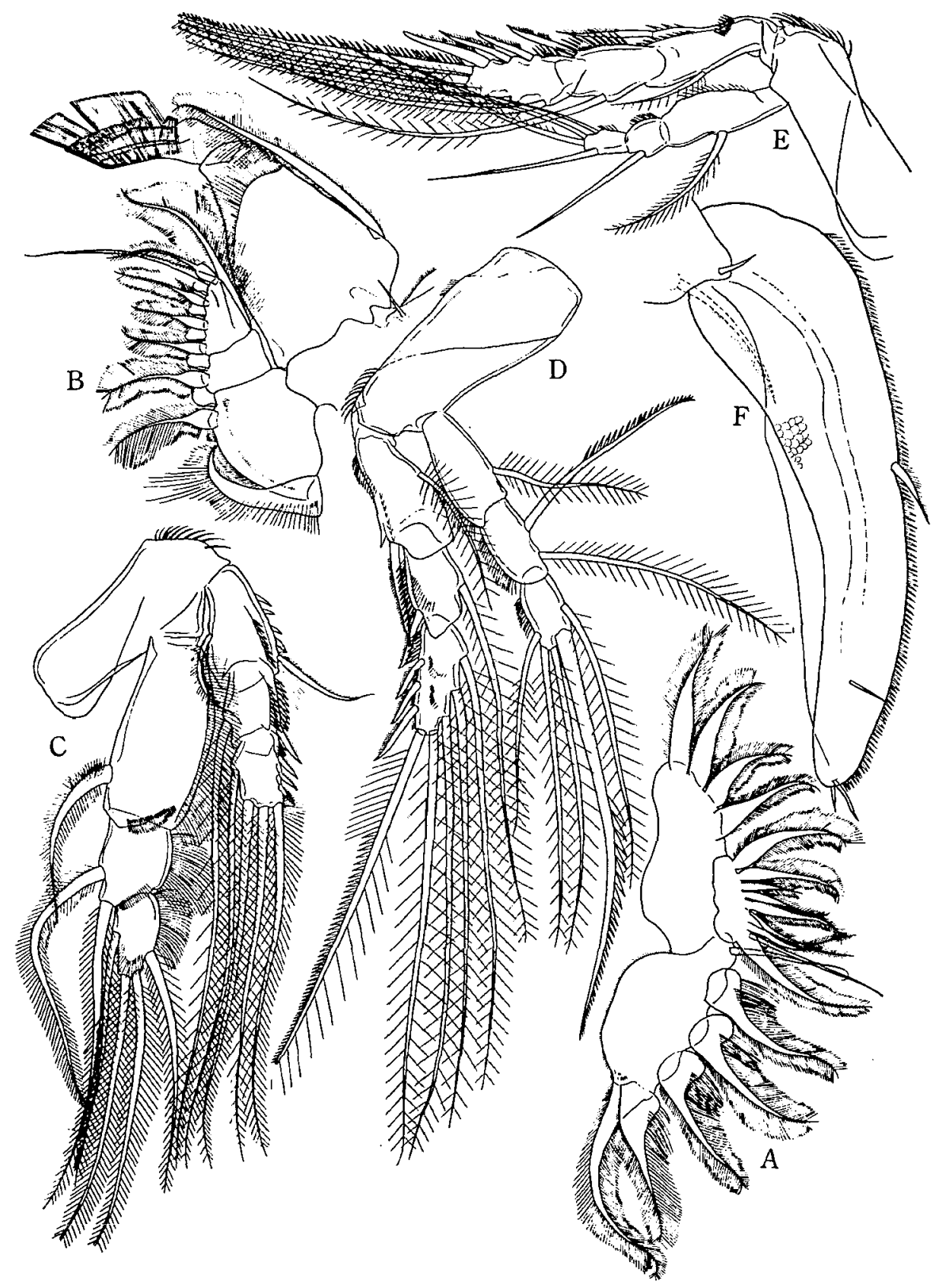

Fig. 2. Porcellidium sp., ovigerous female. A: mandibular palp. B-E: 1st to 4th legs. F: 5th leg, dorsal. 
are fused, with 6 marginal setae, increasing in size proximally. The most proximal seta, however, is short and knife-shaped.

The maxilliped (Fig. 1, I) is small; the coxopodite bears a single fine seta. The basipodite bears two setae on the apical end and a strong, hairy, internal, spiniform process. The endopodite is very small, unsegmented and provided with two setae.

Between the left and right coxopodites of the first four legs there are strong chitinized coxal plates.

The basipodite of the lst leg (Fig. 2, B) is strongly developed, flat, and furnished with a strong external plumose seta. The endopodite is 2-segmented; the 1st segment is large, flattened, and furnished with a strong, slender internal plumose seta and an oblique row of fine hairs on the distal portion; the 2nd segment is very small, and provided with two robust apical spines, each with a longitudinal row of hairs. The exopodite is 3-segmented; the lst segment is rather large and provided with one plumose seta; the 2nd segment is rather short, with two plumose setae; the 3rd segment bears 3 plumose setae on the external margin and one plumose seta and a slender seta at the apex; in addition, there is one strong, slender, plumose seta on the internal margin; all external setae on the segments are swollen proximally and intervened with a small seta between them.

The 2nd to 4th legs are approximately of the same form; as shown in Fig. 2, C-E, both the endo- and exopodites are 3-segmented; the setal formulae of the legs are as follows:

$\begin{array}{lll} & \text { endopodite } & \text { exopodite } \\ \text { leg } 2 & 1,2,121 & 1.1,223 \\ \operatorname{leg} 3 & 1,2,113 & 1,1,323 \\ \text { leg } 4 & 1,1,121 & 1,1,323\end{array}$

The baso-endopodite of the 5 th leg is vestigial, scarcely visible; the external process bears a long seta. Other characters of this leg are already described above and further details are shown in Fig. 2, F.

Remarks: The species somewhat resembles the following four species, $P$, viride Philippi, $P$. ovatum Haller, $P$. scotti Pesta, P. clavigerum Pesta, and $P$. malleatum VERVOORT in appearance, but it differs from all of them in that the distal margin of the furcal rami is rounded. In some respects the species approaches $P$. affine Quidor from Simonstown in South Africa, the South Orkeny Islands and the Kerguelen Islands, from which it differs, however, in having a much smaller size (in female of affine, about $1 \mathrm{~mm}$ long) and in that the greatest width of the furcal ramus is measured at about the distal one-third.

It is very possible that further studies will show this form to be distinct from all the known species of the genus. 


\section{Peltidium ovale Thompson \& A. ScotT}

(Fig. 3, 4)

Peltidium ovale Thompson \& A. Scotт 1903, p. 238, 273, pl. 13, figs. 1-6; Pesta 1935, p. 366, 367; Sewell 1940, p. 143, figs. 5, A-G; LaNg 1948, p. 434, fig. 185 (no. 2).

Male, total length $1.66 \mathrm{~mm}$; greatest diameter $1.02 \mathrm{~mm}$; longest furcal seta much more than $0.4 \mathrm{~mm}$.

The body is ovate, very broad, and solidly built. The cephalothorax and abdomen are furnished with characteristic anastomosing chitinous bands or a skeletal pattern (Fig. 3, A, B). The body preserved in formalin is rather opaque, but the skeletal pattern which is reddish or orange in colour is visible through the translucent integument.

The head and the 1st thoracic somite are completely fused to form the cephalic somite, which is a little shorter than the combined length of the 2 nd to 5 th thoracic somites; the greatest diameter is across the posterior region of the cephalic somite. The epimeral plates of all the thoracic somites, including the 5th thoracic or the 1 st abdominal somite, are well developed, laterally protruded, and their postero-lateral ends are pointed caudally. The 5 th thoracic somite is fused with the lst abdominal somite in the dorso-median portion. The tip of the epimeral plates of the 1st abdominal somite barely reaches the apex of the middorsal process of the posterior portion of the abdomen. Other posterior somites of the abdomen are much reduced and invisible from above (Fig. 3, A and F).

The furcal ramus is about twice as long as broad, cylindrical; there are 6 or 7 marginal-apical setae and 1 appendicular seta; one of the marginal-apical setae is large and very long, remaining setae and appendicular seta are short.

The antennule (Fig. 3, C) is short, 6-segmented; the proportional lengths of segments approach the original account given by THOMPson \& A. ScotT as follows:

$$
\begin{array}{ccccccc}
\text { Segment } & 1 & 2 & 3 & 4 & 5 & 6 \\
& 30 & 26 & 17 & 13 & 4 & 10=100
\end{array}
$$

The 3rd and 4th segments bear each a long aesthetasc.

The antenna (Fig. 3, D) with the basipodite and the lst endopodal segment separate. The exopodite bears 2 segments, provided with 1 and 3 setae respectively. The distal endopodal segment is elongate, with a basal internal seta and 2 distal and 7 apical setae; 3 of the apical setae are fine, 5 of apical setae are geniculate and sword-shaped; the outer margin is spinulose and with a spinule and a flattened tooth.

The mandibular praecoxa (Fig. 4, A) with a big, flattened cutting edge, armed with 9 strong teeth. The palp is 2-segmented; the distal segment bears 9 long and 2 short apical setae and 1 accessory seta on the external margin.

The maxillula (Fig. 4, B) with conspicuous arthrite, with 9 modelled teeth. The coxopodite is small, with a small endite carrying 2 setae. The basipodite bears a 


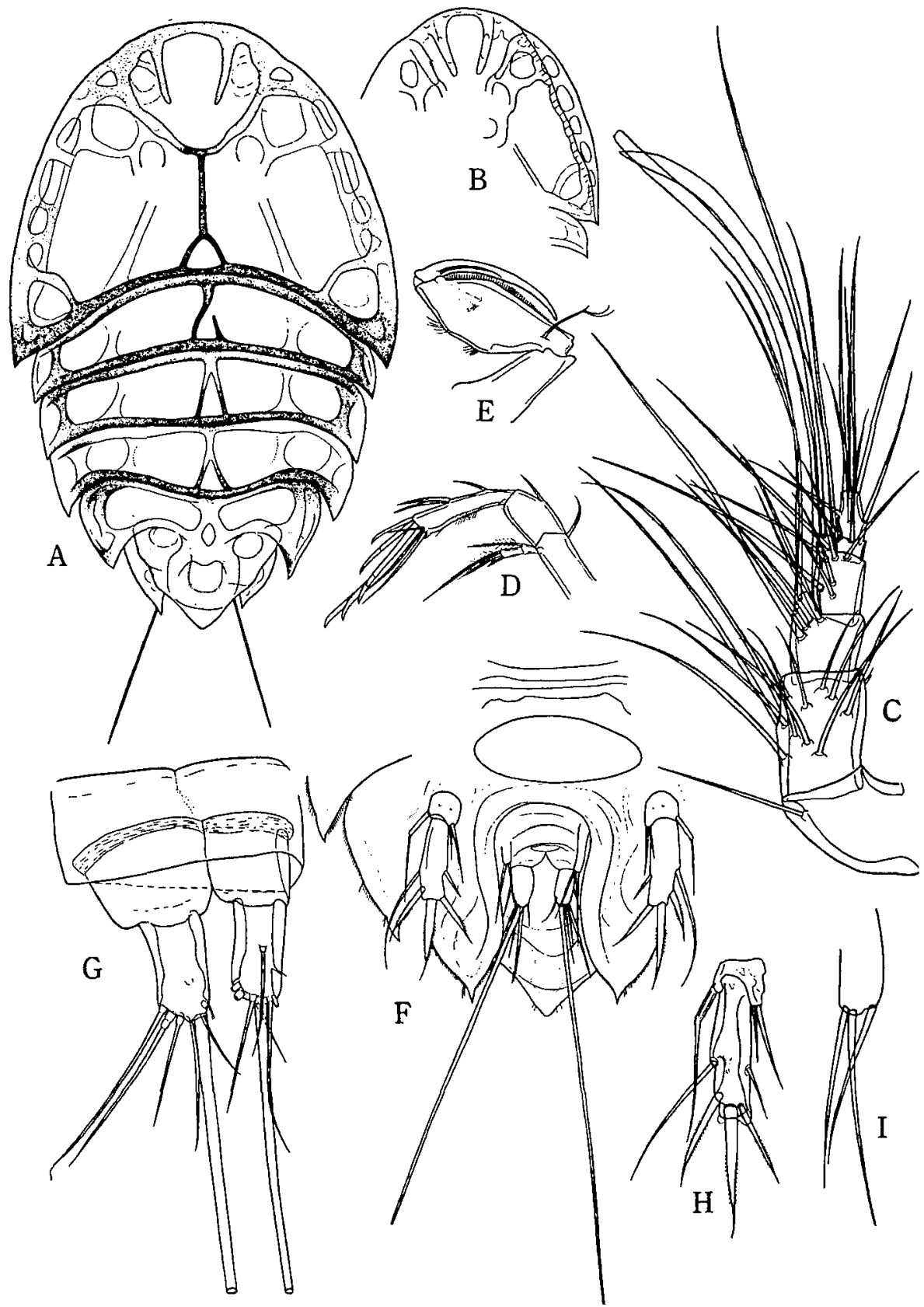

Fig. 3. Peltidium ovale Thompson \& A. Scotr. Male, $1.66 \mathrm{~mm}$ long.

A: whole animal, dorsal. B: anterior portion of body, ventral. C: antennule. D: antenna. E: maxilliped. F: posterior portion of body, ventral. $G$ : anal somite and furcal rami, dorsal. H: 5 th leg. I: right 6 th leg, dorsal. 
small endite with 3 setae, and a small exite with 1 seta.

The proximal portion of the maxilla (Fig. 4, C) with a basal process carrying 2 setae and with small praecoxal and coxal endites. The praecoxal endite bears only 1 seta, whereas the coxal endite with 2 sword-like setae and 1 setose spatulate seta. The basipodite is coalesced into a big endite carrying 1 strong spine. The endopodite is vestigial, represented by 3 setae attached to the basal endite.

The maxilliped (Fig. 3, E) is large, chelate. The basipodite is strongly swollen, bears a row of setules along both margins, and a rather long seta on the proximal portion. The endopodite is unsegmented, claw-shaped, a little shorter than the basipodite, and smooth, with a seta at the base.

The coxopodite of the lst leg (Fig. 4, D) without haired marginal lamella. The basipodite bears a seta on each hairy lateral border. The exopodite is inserted on the distinct score of the basipodite, and 3-segmented. The apex of the lst exopodal segment slightly exceeds the end of the 1st endopodal segment and bears an external seta; the 2 nd segment is one and half times the length of the lst and provided with an internal and an external seta near the distal end; the terminal segment is very small and provided with a lateral curved spinule and 3 big claws of different sizes at the apex, the 2 bigger claws are about twice as long as the smaller one. The endopodite is 2-segmented; the 1st segment is not robust and bears fine hairs along both lateral borders and an internal seta; the 2nd segment is a little shorter than the 1st and bears 3 normal setae, 1 internal and 2 apical, and hairs on the outer border.

The details of the 2nd to 4th legs are shown in Fig. 4, E-G. Their setal formulae are as follows:

$\begin{array}{llr} & \text { endopodite } & \text { exopodite } \\ \operatorname{leg} 2 & 1,2,120 & 1,1,223 \\ \operatorname{leg} 3 & 1,2,220 & 1,1,323 \\ \operatorname{leg} 4 & 1,2,220 & 1,1,323\end{array}$

The 5th leg (Fig. 3, F and $\mathrm{H}$ ) is provided with a very small external lobe of the baso-endopodite which barely reaches $1 / 3$ as long as the exopodite, and bears a fine apical seta. The baso-endopodite is almost rudimentary and provided with 2 setae on the outer angle. The exopodite is about 3 times as long as its width and furnished with 5 marginal setae, one of the apical setae is very strong.

The 6th leg (armature of genital plates) is very small and like a narrow spatulate process bearing 3 apical setae (Fig. 3, F and I).

Remarks: This species has been recorded from the Indian Ocean. Thompson \& A. Scotт (1903) originally described and figured from a female obtained from the washings of the Muttuvaratu pearl oysters and invertebrates in Ceylon and SEwELL (1940) recorded female specimens collected by tow-netting at the Nicobar Islands and from the weeds-washings at the Maldive Archipelago.

In general the present male conforms very well to Trompson \& A. Scott's original 


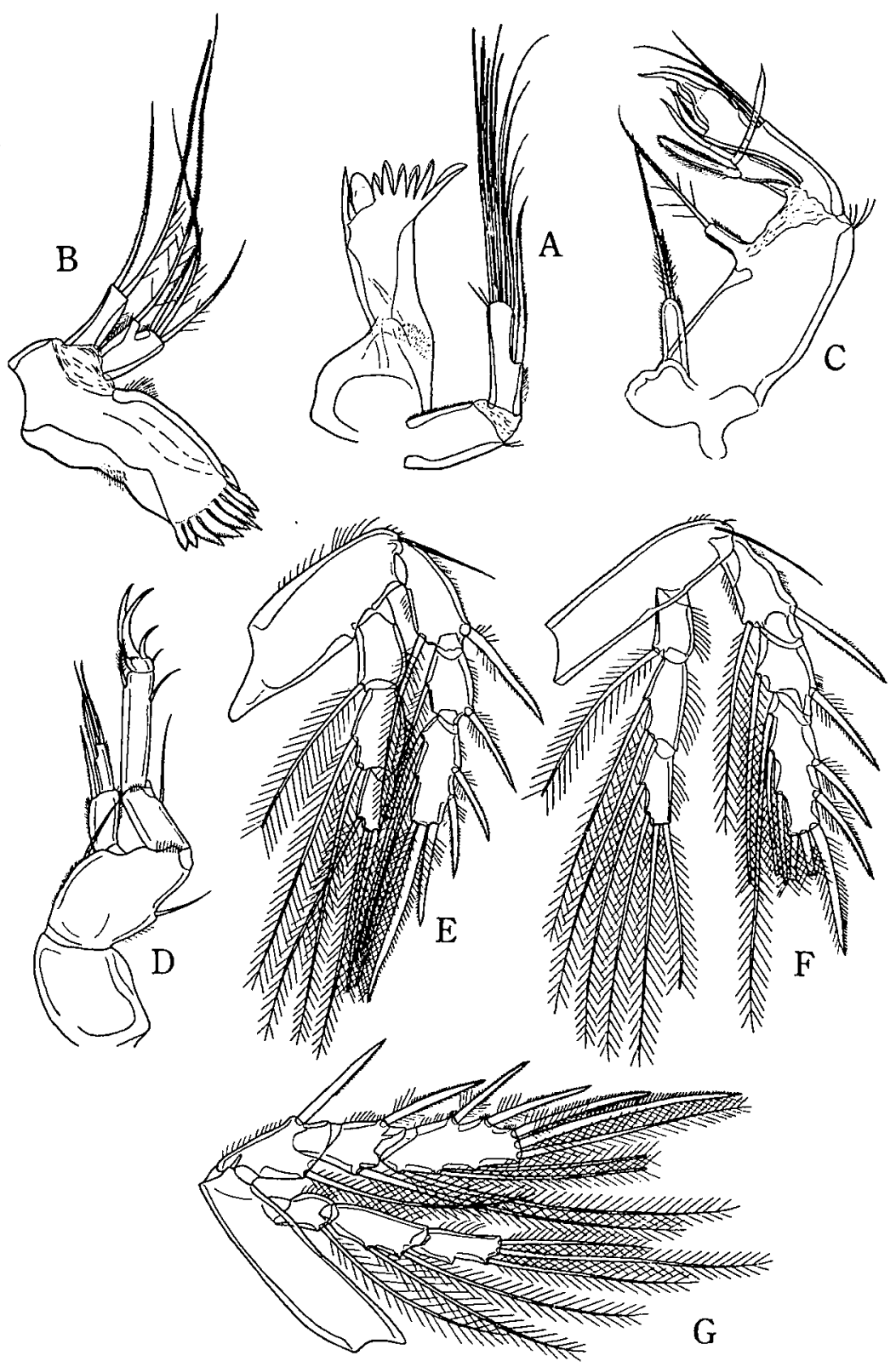

Fig. 4. Pelidium ovale Thompsom \& A. Scotт. Male.

A: mandible. B: maxillula. C: maxilla. D-G: 1st to 4th legs. 
description and figures and also to SEWELL's description in the following characters: the oval body with a similar skeletal pattern in dorsal aspect, the antennule with 6 segments and the swimming legs with a similar structure and spination etc., but the former differs from the latter in some minor details: 1) the body is a little larger than those of the Indian forms (1.6 mm in Thompson \& A. ScotT's specimen and $1.5 \mathrm{~mm}$ in Sewell's, 2) the exopodite of the antenna with 2 segments, while in the SEwELL's with 3 segments, and 3) the proportional lengths of antennular segments are slightly different from those of SEwELL's specimens.

Nicholls (1940, pp. 390-395) states as follows:- "The males are distinguished in each case by three features: 1 , modification of the first antenna, which may not be very marked; 2, structural difference in the first legs; 3 , presence of sixth legs" (op. cit., p. 390).

"P. ovale Thompson and Scotr (1903) was described as a female, the male being unknown. From a comparison of this species with the new species described below as simplex, which is distinguished from ovale chiefly on ceratin differences in the skeletal pattern, it is almost certain that ovale has been described from a male specimen. The urosome is not illustrated, so that it is not possible to discover whether sixth legs were present or not. In simplex the first antenna of the male is not modified, and is indistinguishable from that of the female; the fifth legs also show no difference, and the only distinguishing character, apart from the presence of the sixth legs, is that narrowness of the endopods of the first legs. For these reasons ovale is regarded as having been described from a male and therefore does not from an exception to the rule" (op. cit., p. 391). "As already stated, in view of the similarity of the first antennae in both sexes of simplex and of its resemblance as a whole to ovale, it is assumed that ovale has been described from the male, since the first legs of that species show the usual modification found in males" (op. cit., p. 395).

As pointed out by Nicholls, it reveals that $P$. ovale has been originally described from a male specimen, in view of the close similarity between the Japanese male specimen and that originally described and illustrated as a female.

Besides, the illustrations of a female by SEWELL are not only quite similar to those in the original paper of Thompson \& A. Sсотт but also to those in the present paper, except for a few minor details mentioned above.

Distribution: Ceylon, washings from the Muttuvaratu pearl oysters and invertebrates (Thompson \& A. Scotт 1903). Addu Atoll, the Maldive Archipelago, in weed-washings; Nankauri Harbour, the Nicobar Islands, in a tow-net sample (SEWELL 1940).

\section{Dactylopusia (?) platysoma THOMPSON \& A. ScotT}

(Figs. 5-7)

Daclylophusia plalysoma Thompson \& A. Scotт 1903, p. 272, pl. 11, figs. 13-18; LANG 1948, p. 553, figs. 222 (no. 5), 224 (no. 6). 
Ovigerous female, total length, $0.75 \mathrm{~mm}$; greatest diameter, $0.42 \mathrm{~mm}$; carrying 19 eggs under the abdomen.

The body is rather solid, compressed dorso-ventrally, ovoid in shape as seen from above and the greatest diameter is across the posterior portion of the cephalic somite (Fig. 5, A and C). The surface of the dorsal body integument appears to be covered by a fine reticulation with minute hollowed depressions and pits (Fig. 5, D, E). The colour of the specimen preserved in formalin is light bluish; there is a dorso-median blue spot on the anterior portion and just behind this a pair of dark spot-like sclerotized structures; on both sides near the posterior margin of the cephalic somite a pair of sclerotized dark spot-like structures visible through the translucent integument. Along the posterior margin of the head and the 1st to 5th thoracic somites, including the genital complex and the posterior abdominal somites a conspicuous transverse sclerotized band like a segmentation, coloured deep blue, is visible through the integument.

The head and the 1st thoracic somite seem to be not completely fused, the former is imperfectly separated from the latter by a suture-line. The cephalic somite is fringed with a hyaline lamella carrying several setules laterally and apically.

The rostrum (Fig. 5, A, B, C and E) is bent downward, almost triangular in outline, with a blunt apex.

The 1st to 4th thoracic somites are of about the same breadth and fringed with a hyaline lamella carrying one or two setae or spinules; the 1st somite is longer than the 2nd and 3rd somites combined; the 2nd to 4th somites are successively increased in size, but the 2 nd somite is about $1 / 2$ as long as the 3 rd which is about as long as the 4 th when measured along the middle line; the epimeral plates of the lst thoracic (posterior portion of the cephalic) somite to 4th somites are well developed, laterally protruded and pointed caudally (Fig. 5, A and C); the 5th somite is small, visible from above, a slightly shorter than and about $2 / 3$ as broad as the 4th somite and provided with undeveloped epimeral plates and the flattened phylliform 5th legs attached to the ventral surface.

The abdomen, as described by Thompson \& A. Scotr, is flat and probably 4 segmented, with short furcal rami. The genital complex is large, with convex lateral sides; its sternal wall is deeply concave to form a brood pouch covered by the 5 th legs, in which are contained 19 eggs. The epimeral plates of the genital complex and the following 2 somites are well developed, fringed with acute spinules, interrupted by a short setae posteriorly; the post-lateral portion of the epimeral plates is pointed caudally (Fig. 5, C and F). The 3rd and 4th abdominal somites are small; the 3rd somite bears three setules on the dorso-median portion; the apex of the epimeral plate of the 4th somite barely reaches the distal end of the furcal rami.

In dorsal aspect, the basal portion of the furcal rami is covered by a lamellar plate extending backward from the hind margin of the last abdominal somite.

The antennule is very short (Fig. 5, B), 9-segmented and furnished with an aesthetasc on the 4th segment; the setation is shown in Fig. 6, A. The proportional 


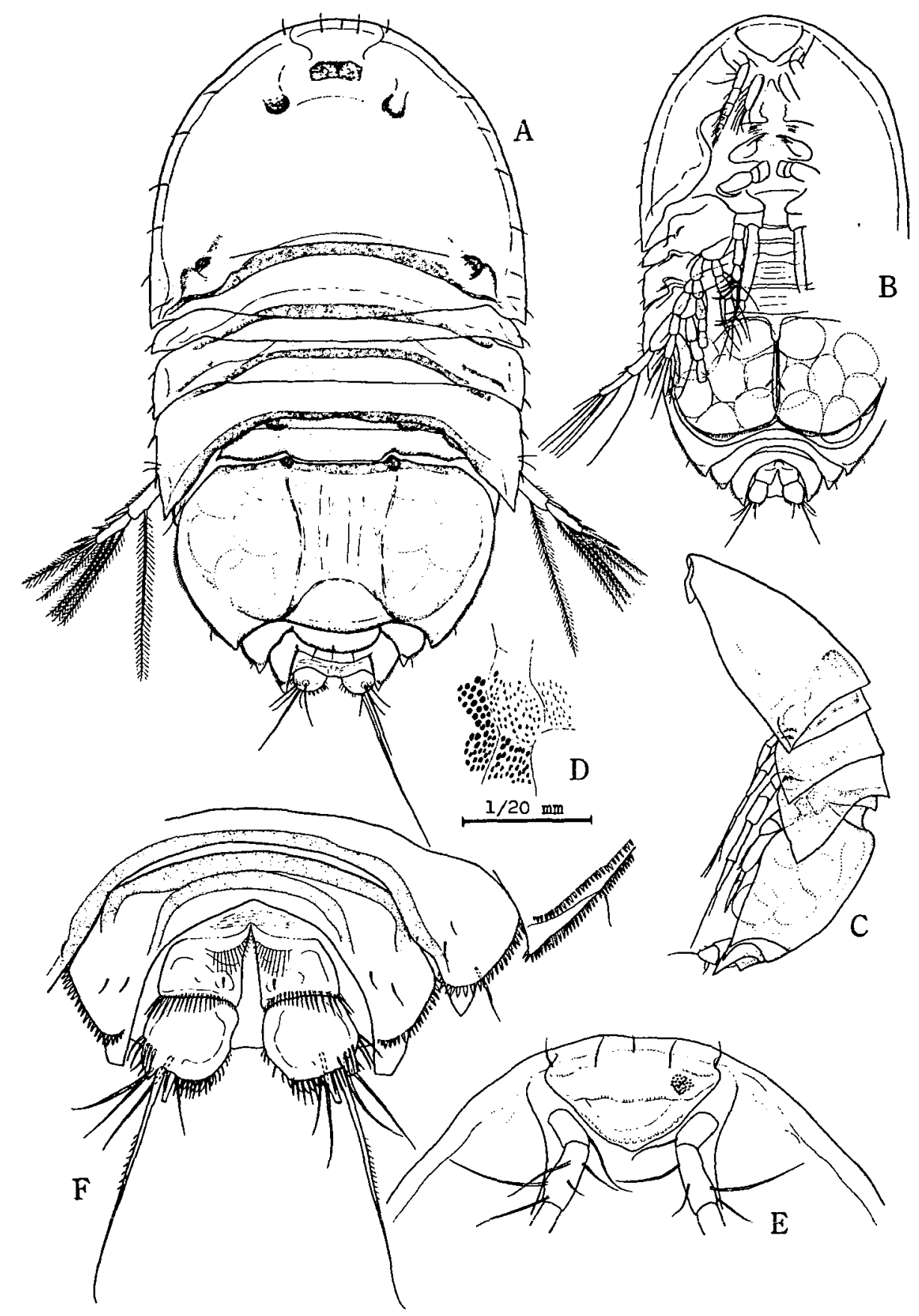

Fig. 5. Dactylopusia (?) platysoma Tномpson \& A. Sсотт. Ovigerous female, $0.75 \mathrm{~mm}$ (inc. furca) long.

A: whole animal, dorsal. B: the same, ventral (setae on the first four legs are partly removed). C: the same, lateral. D: sculpture of integument surface. E: rostrum with basal part of antennulae. F: posterior portion of abdomen with furcal rami, ventral. 
lengths of segments are as follows:

$\begin{array}{lccccccccc}\text { Segment } & 1 & 2 & 3 & 4 & 5 & 6 & 7 & 8 & 9 \\ & 19 & 26 & 17 & 11 & 7 & 8 & 3 & 3 & 7=101\end{array}$

The basipodite of the antenna (Fig. 6, B) bears 1 internal seta. The exopodite is 3 -segmented; the lst segment is short and with a seta; the 2nd segment is very small and bears 1 seta; the 3 rd segment is rather long, with a total of 5 setae. The endopodite is 1-segmented, with 2 setae on the setose inner border, 5 geniculate and 1 fine setae at the apex.

The mandibular praecoxae (Fig. 6, G) are armed each with 5 or 3 strong teeth and 1 basal seta on the cutting edge, and provided with a small palp carrying the slender basipodite bearing 3 setae. The basipodite beras the endo- and exopodite; the endopodite seems to be indistinctly 2 -segmented, with 2 and 5 setae respectively; the exopodite is obscure in segmention and with 2 basal and 3 apical setae.

The praecoxal arthrite of the maxillula bears 6 setae and 1 stout claw. The coxopodite and basipodite are provided each with a distinct endite, carrying 3 or 4 setae respectively. The endopodite is small, fused to the basipodite and with 3 setae. The exopodite is small, too, and with 3 setae.

The syncoxa (praecoxa + coxa) of the maxilla (Fig. 6, E) bears 3 endites, each with 2 or 1 setae. The basipodite bears 1 strong claw with fine internal marginal hairs.

The maxilliped (Fig. 6, F) is rather small and chelate. The coxopodite bears 2 subapical setae. The basipodite is large, internally and externally extended, with a row of fine hairs along the inner margin; there is a small spine on the internal margin at about the middle; the external margin is smooth, with 2 setules. The endopodite is slender, curved, claw-shpaed, with a pointed apex, unsegmented, smooth, and nearly $3 / 4$ as long as the basipodite.

The basipodite of the 1st leg (Fig. 7, A) bears fine hairs on the internal margin and a pair of plumose setae near the distal end. The exo- and endopodites have 3 segments. The exopodite is about as long as the 1st endopodal segment; the 1st exopodal segment is small, about $1 / 2$ of the 2 nd segment and a little longer than the 3 rd, and provided with a distal plumose seta and a row of marginal fine hairs; the 2nd segment bears a row of marginal hairs and one plumose seta on each lateral border; the 3rd segment has a small seta and 4 apical claws which increase the length internally, the inner-most and longest claw much exceeds the length of the exopodite itself. The 1st endopodal segment is very long, bears marginal hairs on both sides and one seta inserted halfway along the internal margin; the 2 nd segment is very small, $1 / 2$ as long as the $3 r d$, and bears 2 small setae at the external distal angle; the distal segment is provided with a few setules, one slender claw on the outer border and one stout claw at the apex the last nearly reaches a half of the total length of the endopodite. 


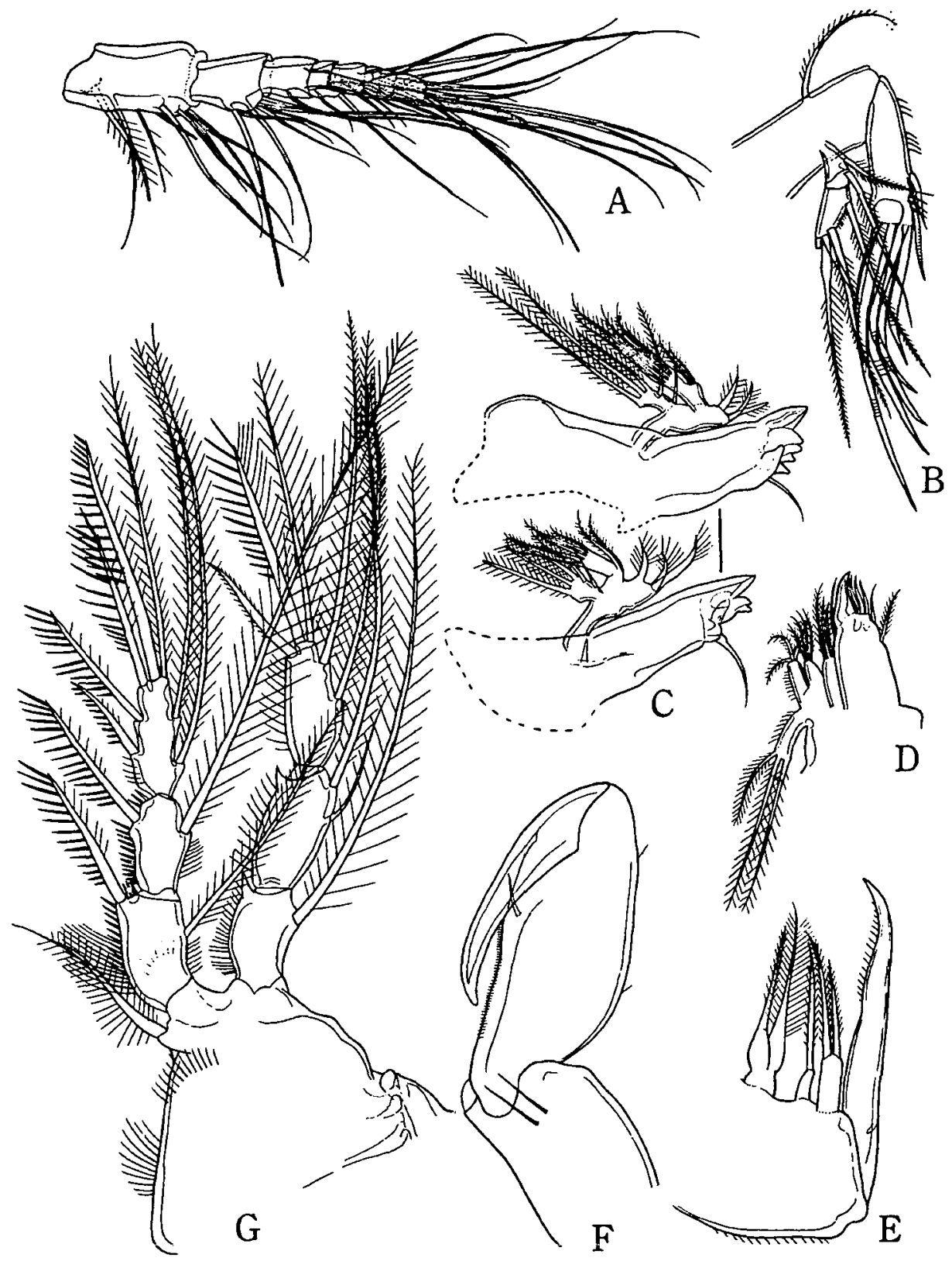

Fig. 6. Dactylopusia (?) platysoma Tномpson \& A. Scort. Ovigerous female.

A: antennule, distal eight segments. B: antenna. C: mandibles. D: maxillula, E: maxilla. F: maxilliped. G: 2nd leg. 


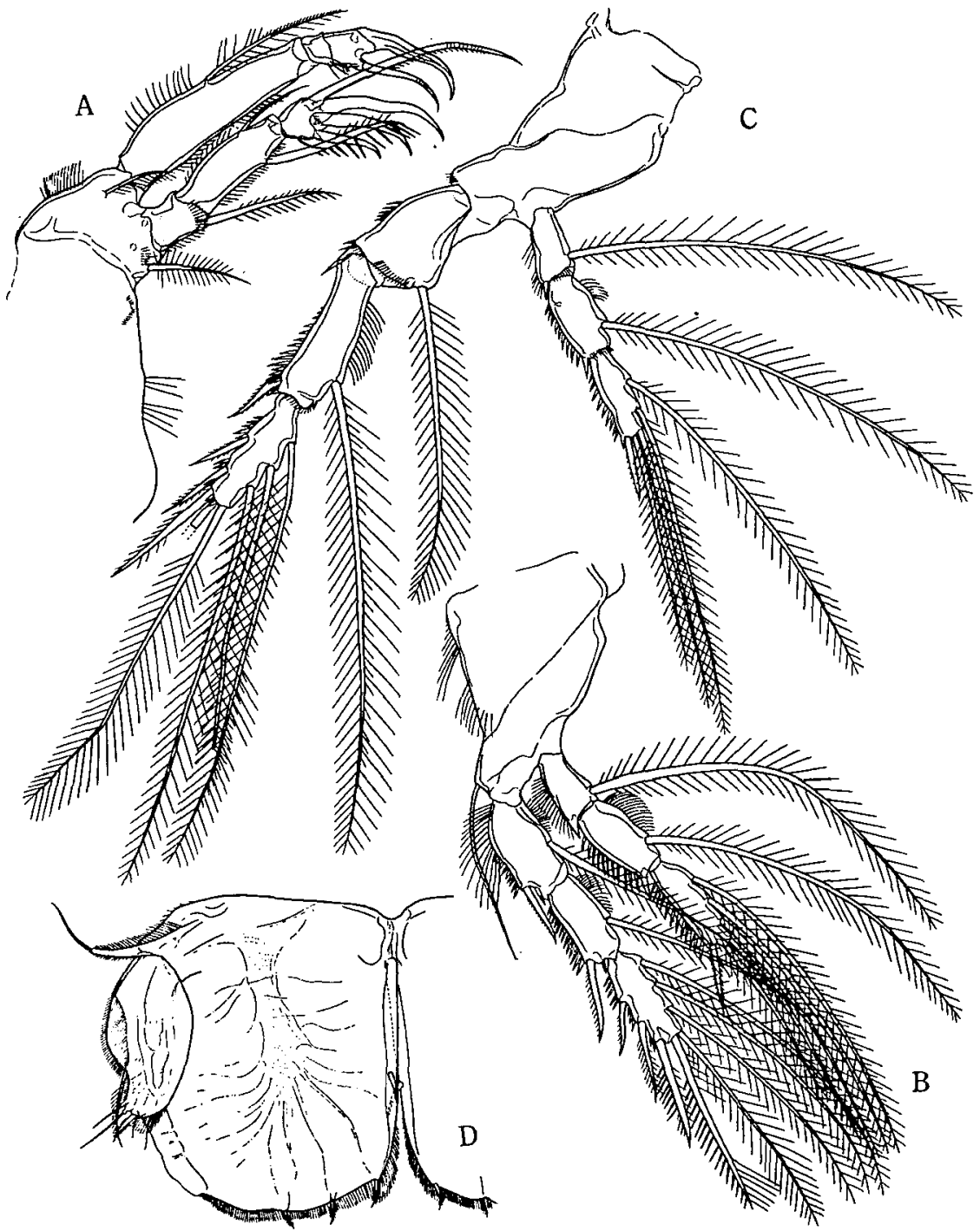

Fig. 7. Dacilopusia (?) platysoma Тномгson \& A. Scotт. Ovigerous female. A: 1st leg. B-D: 3rd to 5 th legs. 
The both rami of the 2 nd to 4 th legs are all 3-segmented and setose. The 2 nd and 3rd legs are very similar in shape, while the 4th legs is different from the preceding 2 pairs in bearing the powerful and longer exopodite, nearly one and two-thirds the length of the endopodite. The details of these legs are shown in Fig. 6, $\mathrm{G}$ and Fig. 7, B and C. Their setal formulae are:

$\begin{array}{lll} & \text { endopodite } & \text { exopodite } \\ \operatorname{leg} 2 & 1,2,221 & 1,1,232 \\ \operatorname{leg} 3 & 1,1,321 & 1,1,323 \\ \operatorname{leg} 4 & 1,1,221 & 1,1,323\end{array}$

The baso-endopodite of the 5 th leg (Fig. 7, D) is flattened, leaf-like in shape, a little longer than wide; there is a short spine at halfway along the internal margin; the distal margin is fringed with marginal hairs and provided with 3 short prominent plumose setae. On the external basal portion of the baso-endopodite there is a filiform external process with marginal fine hairs and a slender apical seta. The exopodite is small, about $1 / 2$ as long as the baso-endopodite, flattened, almost ovoid in shape, and fringed with marginal hairs along the outer and distal margin, carrying one plumose external seta at the distal one-third and 5 setae at the apex.

The furcal rami (Fig. 5, F) is short, nearly one and half times as long as the width; the basal segment bears a row of spiniform setae, decreasing the length internally, along the distal margin and one small seta near the internal angle; on the proximal inner portion there are fine setae in a short semicircular row. The distal segment is rounded in outline; the round apex is fringed with spiniform setae and furnished with 6 prominent apical setae, of which two are much stouter and longer, much more than 2 or 3 times the length of the furcal ramus itself.

Remarks: Thompson \& A. Scotr (1903) proposed Dactylopusia platysoma by one of the six female specimens, $0.62 \mathrm{~mm}$ long, found in the washings from the Muttuvaratu pearl oysters in Ceylon.

The female specimen from Tanabe Bay closely resembles $D$. platysoma in appearance, but the body is a little smaller than the type specimen. The segmentation of the thoracic somites, in dorsal aspect, in the original figures looks very peculiar as compared with that confirmed in the present specimen, probably this is due to the fact that Thompson \& A. Scotт confused the skeletal pattern-like deep blue transverse bands with the true articulations. Otherwise the present specimen well agrees with Thompson \& A. Scotт's description and figures, namely: 1) the general outline of the body, 2) the structure and the spination of the 1st, 4th and 5th legs and the furcal rami, and 3) the proportional lengths of the antennular segments, etc. For the abovementioned features, the present specimen may be safely identified as $D$. platysoma.

The generic name Dactylopusia (for Dactylophusia, used in Thompson \& A. Scotr's paper (1930) and LANG's monograph (1948), read Dactylopusia) is derived from the comment in the original description:- "In general appearance more like a Porcellidium 
than a Dactylophusia, and it is only when the appendages are examined that it is not a Porcellidium; neither can it be used to be a typical Dactylophusia, though provisinally referred to that genus" (Thompson \& A. Scotт 1903, p. 273).

LANG (1948) states as follows in his monograph on p. 543 , "D. platysoma nimmt sowohl hinsichtlich Körperform als P. 5 eine Sonderstellung ein, und ihre systematische Stellung erscheint mir äusserst problematisch. Das es ein Thalestride ist, davon bin ich jetzt indessen überzeugt, und meine frühere Vermutung (LANG 1936g, S. 30), dass sie zu den Peltidiiden gehöre, ist sicher flach. Bevor wir ein sicheres Urteil über ihre Stellung fällen können, ist es indessen notwendig, die Beschreibung der Art an mehreren wesentlichen Punkten zu ergänzen. Sie unter die Dactylopodia-Arten aufzunehmen, seht kaum an, auch lässt sie sich nicht in einer der übringen Gattungen einordnen. Einstweilen muss sie daher beiselte gestellt werden."

Nigholls (1941, p. 386) in a revision of the family Peltidiidae states that "LANG (1936e, p. 30) suggests that Dactylopusia platysoma Thompson and Scoтt (1903) is a Peltidiid and not a Thalestrid, but if it is excluded from the latter family by the swimming legs and flattened body it is equally excluded from the Peltidiidae by the first legs. It appears to be intermediate and should be placed in a separate family." As stated by LANG and Nicholls, this species may be placed in the separate family. The status of the species will be discussed in further study.

Distribution: Ceylon, from washings of the Muttuvaratu pearl oysters.

\section{REFERENCES}

BIERr, R. and T. Tokioka 1968. Dragonet II, an opening-closing quantitative trawl for the study of microvertical distribution of zooplankton and meio-epibenthos. Publ. Seto Mar. Biol. Lab., vol. 15, pp. 373-390, 11 figs.

LANG, K. 1948. Monographic der Harpacticoiden. vol. 1, pp. 1-896, figs. 1-361; vol. 2, pp. 897-1682, figs. 362-607, map. 1-378, A-B. Bokhandeln. Stockholm.

___ 1965. Copepoda Harpacticoidea from the Californian Pacific coast. Kungl. Svenska Vetensl. Handlinger., Bd. 10, Nr. 2, pp. 1-560, pls. 1-303.

Nicholls, A.G. 1941. Littoral Copepoda from South Australia. I. Harpacticoidea. Rec. S. Aust. Mus., Vol. 6, pp. 381-427, 23 figs.

Pesta, O. 1935. Marine Harpacticoiden aus dem Hawaïschen Inselgebiet. Zool. Jahrb., Abt. 1 (Syst.), Bd. 66, pp. 363-379, 8 figs.

Quidor, A. 1906. Copépodes. Expéd. Antarct. Française (1903-1905) commandée par le Dr. Jean Charcor. pp. 1-17, pls. 1-3.

SARs, G.O. 1903-1910. Copepoda Harpacticoida. An account of the Crustacea of Norway with short descriptions and figures of all the species. vol. 5, 368 pp., 203 pls. Bergen.

Sewell, R.B. 1940. Copepoda, Harpacticoida. Sci. Rep. Murray Exped., vol. 7, no. 2, pp. 117382 , figs. 1-88, chart 1 .

Thompson, I.C., \& A. ScotT. 1903. Report on the Copepoda collected by Prof. Herdman, at Ceylon, in 1902. Ceylon Pearl Oyster Fish., Suppl. Rep., no. vii, pp. 227-307, pls. 1-20.

Vervoort, W. 1964. Frec-living Copepoda from Ifluk Atoll in the Caroline Islands with notes on related species. U.S. Nat. Mus. Bulletin. 236. pp. i-ix, 1-431, figs. 1-150. 